Soil Environ. 36(1): 01-12,2017

DOI: $10.25252 / S E / 17 / 41160$

www.se.org.pk

Online ISSN: 2075-1141

Print ISSN: 2074-9546

\title{
Bioavailability of cadmium and nickel to Daucus carota L. and Corchorus olitorius L. treated by compost and microorganisms
}

\author{
Mohamed Mahmoud Mohamed Ahmed ${ }^{1}$, Mohamed Bahy-El-Din Mazen ${ }^{2}$, Nivien Allam Nafady ${ }^{2}$ and \\ Omaima Abdel Monsef ${ }^{1^{*}}$ \\ ${ }^{1}$ Soil, Water and Environment Research Institute (SWERI), Agricultural Research Center (ARC), Assiut, Egypt \\ ${ }^{2}$ Botany and Microbiology Department, Faculty of Science, Assiut University, Assiut, Egypt
}

\begin{abstract}
The research work investigates the impact of the interaction between several rates of compost and microorganisms (bacteria, fungi, mycorrhiza) and their residual effects on growth and metals (Cd and Ni) uptake in carrot (Daucus carota L.) and jew's mallow (Corchorus olitorius L.) grown thereafter. Soil samples were collected from agricultural areas near the superphosphate factory and used for the pot experiments. Microorganisms were isolated from the area under study of which four fungal isolates (Aspergillus niger, A. terreus, Penicillium funiculosum and Fusarium culmorum), one bacterial species (Bacillus sp.) and four species of arbuscular mycorrhizal fungi (AMF) (Acaulospora bireticulata, Gigaspora margarit, Glomus lamellosum and Glomus mosseae) were used for inoculations in the pot experiments. Also, four compost rates were applied equivalent to 0 , 5, 10, $15 \mathrm{t}$ ha- ${ }^{1}$ dry compost. The application of amendments increased the biomass of carrot and jew's mallow plants. The highest reduction of $\mathrm{Cd}$ and Ni contents in both plants were observed by the simultaneous applications of compost with microbes or AMF to polluted soils. The DTPA extractable values of Cd and Ni in soils of jew's mallow plants were higher those of carrot plants. The transfer factor (TF) for Cd and Ni in both plants decreased significantly $(p<0.05)$ as the result of interaction between compost and microorganism. This study concluded that the integration between compost and microorganisms have a positive effect on reducing the bioavailability of the metal polluted soil.
\end{abstract}

Keywords: Compost, microorganisms, polluted soil, remediation, transfer factor

\section{Introduction}

Many heavy metals (HMs) including cadmium (Cd) are non-essential and toxic for plant growth (Zhiqiang et al., 2009; Lai et al., 2012), but plant takes them up rapidly when present in growing medium like soil (Fusconi et al., 2006). Cd toxicity is a problem of increasing significance for ecological, evolutionary, nutritional, and environmental reasons. High $\mathrm{Cd}$ accumulations in the plants adversely affect the absorption and transport of essential elements (Sangwan et al., 2013). Different plant processes such as respiration, photosynthesis, water and nutrient uptake of plants are badly affected by $\mathrm{Cd}$ (Kuo and Kao, 2004). Cadmium reduces root growth because of the reduction of the rate of new cell production (Liu et al., 2004), inhibits the activities of antioxidative enzymes of plants (Correa $e t$ $a l ., 2006$ ) and induces oxidative stress in cells (Sandalio et al., 2001). Nickel (Ni) is an important toxic heavy metal, and pollution by $\mathrm{Ni}$ has gained importance due to the greater understanding of its persistence and toxicity in the ecosystems (Alemayehu and Lennartz, 2010). Studies on the contamination of $\mathrm{Ni}$ in soils and plants have so far been restricted to highly industrialized temperate regions (Al-
Hamdan and Reddy, 2006). Ni adversely affects plant growth by altering different physiological and metabolic processes (Aziz et al., 2015). So the accumulation of these metals in soil may cause the environmental pollution to a great extent.

Soil remediation can be defined as the combined use of soil amendments (organic or inorganic) and agronomic practices to remove pollutants from the environment or to decrease their toxicity. This technique has many advantages compared with other remediation procedures such as low economic costs and the possibility of being applied to soils, causing a minimum environmental impact (Angelova et al., 2010). Bioremediation is an option that offers the possibility to destroy or render harmless various contaminants using natural biological activity. As such, it uses relatively low-cost, low-technology techniques, which generally have a high public acceptance and can often be carried out on site (Vidali, 2001). Bioremediation uses biological agents, mainly microorganisms, yeast, fungi or bacteria to clean up contaminated soil and water (Strong and Burgess, 2008; Dixit et al., 2015). These microorganisms are known to develop and adopt different

\footnotetext{
*Email: omaimaabdelmonsef@yahoo.com
} 
detoxifying mechanisms such as biosorption, bioaccumulation, biotransformation and biomineralization Mycorrhizal fungi in a metal-polluted soil are the ones which provide a direct link between the soil and roots by interacting with their host plants to form a symbiotic relationship in the contaminated land (Leung et al., 2007). There is evidence that arbuscular mycorrhizal (AM) fungi can play a vital role in increasing the tolerance of some plants to toxic metal contamination by developing the metal tolerance of the fungi themselves and binding the metals to polyphosphates within the fungal hyphae implicated (Barea et al., 2005; Morgan et al., 2005).

The objectives of this study were to investigate: 1) Direct effect of compost and microorganisms on growth and metal contents in carrot (Daucus carota L.). 2) Residual effect of compost and microorganisms on growth and metal contents in jew's mallow (Corchorus olitorius L.). 3) The impact of combination between compost and microorganisms on the bioavailability of $\mathrm{Cd}$ and $\mathrm{Ni}$ in polluted soil. 4) The transfer factor of $\mathrm{Cd}$ and $\mathrm{Ni}$ to evaluate the concentration of these metals in plants taken from the polluted soil. Our results point to the important of biofertilizers (compost and microorganisms) in heavy metal polluted soils.

\section{Materials and Methods}

\section{Soil collection and characterization}

The soil used in the current investigation was collected from agricultural areas near the superphosphate factory placed $9 \mathrm{~km}$ north of Assiut city $\left(27^{\circ} \mathrm{N}\right.$ and $\left.31^{\circ} \mathrm{E}\right)$. Soil samples have been taken at $0-15 \mathrm{~cm}$ depth. Soil samples were dried at $40{ }^{\circ} \mathrm{C}$ for $48 \mathrm{~h}$ and passed through a $1 \mathrm{~mm}$ sieve. The mechanical analysis was carried out by using the pipette method (Piper, 1950). Field capacity was determined by using the pressure plate apparatus (Klute, 1986). The water saturation capacity, total calcium carbonate, organic matter, electrical conductivity, soluble cations, soluble anions, available phosphorus of the studied soil samples were measured according to Jackson (1973). Soil pH was measured according to Mclean (1982). Micro Kjeldahl method (Black, 1965) was used to detect soil total nitrogen. The total content of $\mathrm{Cd}$ and $\mathrm{Ni}$ in soil sample were digested by aqua regia (hydrochloric acid and nitric acid) according to Cottenie et al. (1982) and determined by Inductively Coupled Plasma Spectrometry (Ultima 2 JY Plasma). The diethylene triamine penta acetic acid extracting (0.005 M DTPA, 0.1 TEA (triethanolamine), and $0.01 \mathrm{M} \mathrm{CaCl}_{2}$, adjusted to $\mathrm{pH} 7.3$ ) solution (Lindsay and Norvell, 1978) was employed to extract $\mathrm{Cd}$ and $\mathrm{Ni}$ as a potential indicator of plant-available heavy metals from soils.

\section{Preparation and characterization of compost}

Compost resulting from the raw shredded maize residues mixed with sheep manure and peanut residues was added to the polluted soil. Compost samples were dried at $70^{\circ} \mathrm{C}$ to constant weight ground. Values of $\mathrm{pH}$ and $\mathrm{EC}$ were determined as described by Jackson (1973). The organic matter (OM) content of compost was analyzed by weight loss on ignition at $430^{\circ} \mathrm{C}$ for $24 \mathrm{~h}$ and total organic carbon (TOC) was calculated from (OM) to the following equations (Navarro et al., 1993):

$$
\mathrm{OM}=\left[\left(\mathrm{W}_{105}-\mathrm{W}_{430}\right) / \mathrm{W}_{105}\right] \times 100
$$

Where $\mathrm{W}_{105}=$ oven dry weight of mass at $105^{\circ} \mathrm{C} ; \mathrm{W}_{430}$ $=$ furnace dry weight of mass at $430^{\circ} \mathrm{C}$

$$
\mathrm{TOC}=0.51 \times \mathrm{OM}+0.48
$$

Compost samples were digested using a mixture of $\mathrm{H}_{2} \mathrm{O}_{2}$ and $\mathrm{H}_{2} \mathrm{SO}_{4}$. Total nitrogen was determined by using the micro-kjeldahl procedure (Jackson, 1973). Total phosphorus and potassium were determined by Page et al. (1982). One gram of samples was wet digested using a nitric- perchloric acids mixture $\left(\mathrm{HNO}_{3}+\mathrm{HClO}_{4}\right)$ to determine total $\mathrm{Cd}$ and $\mathrm{Ni}$ according to AOAC (1990).

\section{Preparation of microbial inoculums}

Aspergillus niger, A. terreus, Penicillium funiculosum and Fusarium culmorum were isolated from the polluted site under investigation on Potato Dextrose Agar (PDA). Purified fungal isolates were identified on the basis of macroscopic and microscopic features (Raper and Fennell, 1965; Pitt, 1985; Leslie and Summerell, 2006). The microbial inoculum was prepared by inoculating the fungus on Potato Dextrose Broth (PDB: 200g potatoes, 20g glucose and $1000 \mathrm{ml}$ distilled water) at $28^{\circ} \mathrm{C}$ for 5 days and the mycelia harvested by filtration through a nitrocellulose filter and air drying. Inoculum potential of A. niger, A. terreus, $P$. funiculosum and $F$. culmorum was $10^{4} \mathrm{cfu} / \mathrm{g}$.

Bacillus sp. was isolated on the nutrient agar medium where the morphological characteristics of the bacterial isolate were determined by colony characterization: The growth characteristics of the single bacterial colonies (colony shape, size, edge, surface, color, pigmentation) were detected as macroscopic features. Cell morphology: including cell shape, motility and Gram staining was detected. An inoculum of Bacillus sp. was prepared by inoculation it on Nutrient Broth (NB: $5 \mathrm{~g}$ peptone, $3 \mathrm{~g}$ beef extract, $5 \mathrm{~g} \mathrm{NaCl}$ and $\mathrm{pH} 6.8 \pm 0.2$ ) for 48 hours at $25^{\circ} \mathrm{C}$ under aseptic conditions and the inoculum potential was $10^{6}$ $\mathrm{cfu} / \mathrm{g}$. The compatible mixed culture was used as A. niger, A. terreus, $P$. funiculosum and F. culmorum and Bacillus 
sp. which showed mutual interactions without any inhibition (Mohammad et al., 2011).

\section{Preparation of mycorrhizal inoculum}

Acaulospora bireticulata, Gigaspora margarit, Glomus lamellosum and Glomus mosseae were isolated from the contaminated soil under study by wet sieving and decanting technique (Gerdemann and Nicolson, 1963). Isolates were identified morphologically according to Walker and Schübler (2004) and Internet information by INVAM (2006). The most dominant native populations of mycorrhizae were propagated in a mixture of sand and bulk soil (1:1v/v) using Zea mays L. seedlings as host plants. The trap cultures were maintained for 2 months in a greenhouse and the dry rhizosphere soil containing spores, hyphae and colonized root fragments was used as inoculum. One hundred gram of AM fungi inoculums were placed below seeds of tested plant (approximately contain 10 spores/g soil). Control treatments received the same volume of autoclaved inoculum.

\section{Experimental set up and design}

\section{First experiment}

The plastic pots were filled with $18 \mathrm{~kg}$ of polluted soil under study and planted with carrot as a root vegetable grown during the winter season. Five seeds of carrot were cultivated in each pot. Plants were then irrigated to field capacity. Mineral fertilizers (NK) were added for all treatments on three periods. Plant samples were harvested after 100 days from planting. The pot experiment carried out in a greenhouse of Assiut Agricultural Research Station, Egypt. The factorial experiment in completely randomized block design was performed and divided into twelve groups and treated as the follow ( 3 pots have been used for each treatment):

$\checkmark$ Plants of the $1^{\text {st }}$ group were left without any treatments NC (control).

$\checkmark$ Plants of the $2^{\text {nd }}$ group were inoculated with microbes (M: four fungal species + one bacterial species) (control).

$\checkmark$ Plants of the $3^{\text {rd }}$ group were inoculated with four species of arbuscular mycorrhizal fungi (AM) (control).

$\checkmark \quad$ Plants of the $4^{\text {th, }} 5^{\text {th }}$ and $6^{\text {th }}$ groups were treated with compost equivalent 5, 10 and $15 \mathrm{t}$ compost ha ${ }^{-1}$.

$\checkmark \quad$ Plants of the $7^{\text {th }}, 8^{\text {th }}$ and $9^{\text {th }}$ groups were inoculated with microbes and treated with 5,10 and $15 \mathrm{t}$ compost ha ${ }^{-1}$.

$\checkmark$ Plants of the $10^{\text {th }}, 11^{\text {th }}$ and $12^{\text {th }}$ groups were inoculated with AM fungi and treated with 5, 10 and $15 \mathrm{t}$ compost ha ${ }^{-1}$.

\section{Second experiment}

The plastic pots after carrot harvesting were planted with jew's mallow as a leaf vegetable grown during the summer season. Five seeds of jew's mallow were grown in each pot without adding any compost or inoculums, only mineral fertilization was added. Plants were maintained at a soil water potential of field capacity. Plant samples were harvested after 30 days from planting.

\section{Plant analysis}

Growth measurements of plant samples were taken. The dry weights of plant parts (root and shoot) were recorded after drying in a forced air oven at $65^{\circ} \mathrm{C}$ for $48 \mathrm{~h}$. A half gram of each sample was wet digested using a nitricperchloric acids mixture $\left(\mathrm{HNO}_{3}+\mathrm{HClO}_{4}\right)$ according to the procedure of Tedesco et al. (1995) to determined total Cd and $\mathrm{Ni}$ in plant tissues.

\section{Assessment of mycorrhizal colonization}

Mycorrhizal colonization of carrot and jew's mallow roots was determined according to Phillips and Hayman, (1970). Roots were separated from soil, washed and cut into $1 \mathrm{~cm}$ long pieces. The segments were cleared with $10 \%$ (w/v) $\mathrm{KOH}$ at $70{ }^{\circ} \mathrm{C}$ for $20 \mathrm{~min}$ and stained with $0.05 \%$ (w/v) Trypan blue. Thirty pieces of roots from each sample were randomly selected and examined. Colonization measures the prevalence of all fungal structures in roots, including arbuscules, vesicles, coils and fungal hypha.

\section{Soil to plant transfer factor (TF) of heavy metals}

To characterize quantitatively the transfer of an element from soil to plant, the soil-plant Partition Coefficient or Transfer Factor (TF) that expresses the ratio of contaminant concentration in plant parts to concentration in dry soil was used (Cui et al., 2004).

$$
\mathrm{TF}=\mathrm{C}_{\text {plant }}\left(\mathrm{mg} \mathrm{kg}^{-1} \text { dry weight }\right) / \mathrm{C}_{\text {soil }}\left(\mathrm{mg} \mathrm{kg}^{-1} \text { dry weight }\right)
$$

"Where $\mathrm{C}_{\text {plant }}$ and $\mathrm{C}_{\text {soil }}$ represented the concentration of metal in the plant material and soils on dry weight basis, respectively".

\section{Statistical Analysis}

Results were processed and analyzed by using SPSS statistical analysis package for Windows $®$. Data is reported as a mean \pm standard deviation of the mean unless otherwise stated. A p-value of $<0.05$ was considered significant. Two-way analysis of variance was performed (ANOVA) on the pairs of variables likely to exhibit correlation. 


\section{Results}

\section{Soil and compost properties}

The results of the physico-chemical characterization of the polluted soil under investigation are presented in Table 1. The total concentrations of heavy metals ( $\mathrm{Cd}$ and $\mathrm{Ni}$ ) in soil show the magnitude of contamination and thus the potential for plant metal uptake. It was observed that $\mathrm{Cd}$ and $\mathrm{Ni}$ contents were 4.30 and $54.75 \mathrm{mg} \mathrm{kg}^{-1}$ dry soil, respectively while DTPA-extractable of $\mathrm{Cd}$ and $\mathrm{Ni}$ contents were 0.053 and $0.501 \mathrm{mg} \mathrm{kg}^{-1}$ dry soil, respectively. The electrical conductivity (EC) was up to $2.55 \mathrm{dS} \mathrm{m}^{-1}$. Cations and anions composition of the soil is presented in Table 1. $\mathrm{Ca}^{++}$value was $6.50 \mathrm{mmol}_{\mathrm{c}} \mathrm{L}^{-1}$, while $\mathrm{Na}^{+}$content was 4 $\mathrm{mmol}_{\mathrm{c}} \mathrm{L}^{-1}$. The mean value of total phosphorus content was $150 \mathrm{mg} \mathrm{kg}^{-1}$. On the other hand, the organic matter content $(\mathrm{OM})$ in soils was $15.9 \mathrm{~g} \mathrm{~kg}^{-1}$ soil.

Table 1: Soil physico-chemical properties

\begin{tabular}{|c|c|}
\hline Soil properties & Value \\
\hline Soil texture & Silt \\
\hline Clay \% & 8.96 \\
\hline Silt $\%$ & 84 \\
\hline Sand $\%$ & 7.04 \\
\hline Field capacity $(\%)$ & 25.84 \\
\hline Water saturation $(\%)$ & 55.24 \\
\hline Total $\mathrm{CaCO}_{3}\left(\mathrm{~g} \mathrm{~kg}^{-1}\right.$ soil $)$ & 15.2 \\
\hline Organic matter $\left(\mathrm{g} \mathrm{kg}^{-1}\right.$ soil $)$ & 15.9 \\
\hline $\mathrm{EC}\left(\mathrm{dS} \mathrm{m}{ }^{-1}\right)$ & 2.55 \\
\hline $\mathrm{pH}$ & 6.50 \\
\hline \multicolumn{2}{|l|}{ Soluble cations $\left(\mathbf{m m o l}_{\mathrm{c}} \mathbf{L}^{-1}\right)$} \\
\hline $\mathrm{Ca}^{++}$ & 6.50 \\
\hline $\mathrm{Mg}^{++}$ & 1.55 \\
\hline $\mathrm{Na}^{+}$ & 4.00 \\
\hline $\mathrm{K}^{+}$ & 0.14 \\
\hline \multicolumn{2}{|l|}{ Soluble anions $\left(\mathrm{mmol}_{c} \mathbf{L}^{-1}\right)$} \\
\hline $\mathrm{CO}_{3}^{-} \mathrm{HCO}_{3}^{-}$ & 0.10 \\
\hline $\mathrm{Cl}^{-}$ & 5.00 \\
\hline $\mathrm{SO}_{4}^{--}$ & 7.20 \\
\hline Total N ( $\mathrm{g} \mathrm{kg}^{-1}$ soil $)$ & 1.56 \\
\hline Available $\mathrm{P}\left(\mathrm{mg} \mathrm{kg}^{-1}\right.$ soil $)$ & 150 \\
\hline \multicolumn{2}{|c|}{ Total heavy metals ( $\mathrm{mg} \mathrm{kg}^{-1}$ soil): } \\
\hline $\mathrm{Cd}$ & 4.30 \\
\hline $\mathrm{Ni}$ & 56.75 \\
\hline \multicolumn{2}{|c|}{ DTPA-extractable ( $\mathrm{mg} \mathrm{kg}^{-1}$ soil): } \\
\hline $\mathrm{Cd}$ & 0.053 \\
\hline $\mathrm{Ni}$ & 0.501 \\
\hline
\end{tabular}

The results of the chemical characterization of the amendment compost are presented in Table 2. Cadmium and nickel concentrations were 0.116 and $2.770 \mathrm{mg} \mathrm{kg}^{-1}$ dry compost, respectively in the dried compost. The $\mathrm{N}$ and organic matter contents of the compost were high as compared to their contents in the soil under investigation. Meanwhile, the $\mathrm{Cd}$ and $\mathrm{Ni}$ contents of the compost were low as compared to their contents in the soil. The organic matter and organic carbon contents in compost were $54.09 \%$ and $28.07 \%$, respectively.

Table 2: Compost chemical properties

\begin{tabular}{lc}
\hline Compost property & Value \\
\hline $\mathrm{pH}$ & 8.6 \\
$\mathrm{EC}\left(\mathrm{dS} \mathrm{m}{ }^{-1}\right)$ & 6.14 \\
Organic matter (OM) \% & 54.09 \\
Organic carbon (OC) \% & 28.07 \\
Total N \% & 2.09 \\
Total P \% & 0.35 \\
Total K \% & 1.59 \\
C/N Ratio & 13.45 \\
Total heavy metals ( $\mathrm{mg} \mathrm{kg}^{-1}$ compost): & \\
Cd & 0.116 \\
$\mathrm{Ni}$ & 2.770 \\
\hline
\end{tabular}

Plant biomass: Data illustrated in Table 3 showed the effect of different rates of compost on carrot growth in the presence or absence of microorganisms and their residual effects on jew's mallow growth. The results of two tested plant tolerance efficiency were prompted and all plants had high tolerance to soil polluted with $\mathrm{Cd}$ and $\mathrm{Ni}$. This was showed by the absence of inhibition of plant growth and no visible physical damage that showed toxicity symptoms at all tested plants. The results showed that the biomass of shoots and roots of carrot significantly $(\mathrm{P}<0.05)$ increased in response of amendment of different compost rates, microbes (fungal-bacterial inoculation) and AM fungi to the polluted soil. Root dry matter was high with compost $(5 \mathrm{t}$ $\mathrm{ha}^{-1}$ ) in microbes (M) inoculated plants. The mean values of carrot roots length ranged between 11.68 and $14.47 \mathrm{~cm}$. The highest value of the carrot shoot length was $28.49 \mathrm{~cm}$ in plants inoculated with AM fungi individually. The dry weight of roots and shoots of jew's mallow plants was highly significant $(\mathrm{P}<0.05)$, increased as a result of the residual effect of microbes, AM fungi and different rates of compost. In general, inoculation with AM fungi improved roots and shoots dry weight of jew's mallow with or without compost (Table 3). Plant height of jew's mallow was highest under residual effect of compost and microbes compared with control plants (NC at zero compost). The mean value of jew's mallow height ranged between 28.27 and $42.47 \mathrm{~cm}$ with the highest value recorded in mycorrhizal plants. Two-way ANOVA indicated that the factor "compost" affected significantly $(\mathrm{p}<0.01)$ all growth measurements of carrot and jew's mallow except shoot dry weight of carrot while factor "inoculation" and interaction of " compost $\times$ inoculation" significantly $(\mathrm{p}<0.05)$ affected all growth and yield measurements for both plants. 
Table 3: Effect and residual effect of compost, microbes and arbuscular mycorrhizal fungi on biomass of carrot and jew's mallow. Mean \pm SD $(n=9)$

\begin{tabular}{|c|c|c|c|c|c|}
\hline \multirow{3}{*}{ Compost rates } & \multirow{3}{*}{ Inoculation } & \multicolumn{4}{|c|}{ carrot } \\
\hline & & \multicolumn{2}{|c|}{ Dry weight $\left(\right.$ g plant $\left.^{-1}\right)$} & \multicolumn{2}{|c|}{ Plant height $\left(\mathrm{cm}\right.$ plant $\left.^{-1}\right)$} \\
\hline & & Root & Shoot & Root & Shoot \\
\hline \multirow{4}{*}{0 t ha ${ }^{-1}$} & $\mathrm{NC}$ & $4.92 \pm 0.53^{a}$ & $1.78 \pm 0.16^{a}$ & $12.24 \pm 0.56^{a b}$ & $21.38 \pm 1.70^{a}$ \\
\hline & $\mathbf{M}$ & $6.72 \pm 0.35^{f}$ & $2.95 \pm 0.16^{d e}$ & $14.47 \pm 0.83^{e}$ & $27.15 \pm 1.05^{e f g}$ \\
\hline & $\mathbf{A M}$ & $5.23 \pm 0.10^{a b}$ & $2.98 \pm 0.18^{e}$ & $13.53 \pm 0.65^{\text {cde }}$ & $28.49 \pm 0.78^{g}$ \\
\hline & NC & $6.06 \pm 0.26^{e}$ & $2.75 \pm 0.06^{b c d e}$ & $14.17 \pm 0.29^{d e}$ & $25.87 \pm 1.60^{d e f}$ \\
\hline \multirow[t]{3}{*}{$5 \mathrm{t} \mathrm{ha}^{-1}$} & $\mathbf{M}$ & $6.77 \pm 0.13^{f}$ & $2.82 \pm 0.21^{\text {cde }}$ & $12.64 \pm 0.54^{a b c}$ & $27.28 \pm 1.36^{f g}$ \\
\hline & $\mathbf{A M}$ & $5.47 \pm 0.32^{b c d}$ & $2.64 \pm 0.24^{b c d e}$ & $13.25 \pm 0.67^{b c d}$ & $27.29 \pm 1.12^{f g}$ \\
\hline & $\mathrm{NC}$ & $5.86 \pm 0.27^{c d}$ & $2.59 \pm 0.12^{b c d e}$ & $12.39 \pm 0.21^{a b c}$ & $24.87 \pm 0.27^{b c d e}$ \\
\hline \multirow{3}{*}{$10 \mathrm{t} \mathrm{ha}^{-1}$} & $\mathbf{M}$ & $6.07 \pm 0.12^{e}$ & $2.34 \pm 0.16^{b}$ & $13.07 \pm 0.67^{b c d}$ & $25.21 \pm 1.69^{\text {cdef }}$ \\
\hline & $\mathbf{A M}$ & $5.05 \pm 0.28^{a b}$ & $2.42 \pm 0.15^{b c}$ & $14.38 \pm 0.30^{e}$ & $24.59 \pm 0.93^{b c d}$ \\
\hline & NC & $5.84 \pm 0.03^{d e}$ & $2.52 \pm 0.59^{b c d}$ & $12.29 \pm 0.79^{a b}$ & $23.47 \pm 1.37^{a b c}$ \\
\hline \multirow[t]{2}{*}{$15 \mathrm{t} \mathrm{ha}^{-1}$} & $\mathbf{M}$ & $5.60 \pm 0.37^{\text {cde }}$ & $2.50 \pm 0.02^{b c}$ & $11.68 \pm 0.77^{a}$ & $22.02 \pm 1.78^{a}$ \\
\hline & $\mathbf{A M}$ & $5.59 \pm 0.23^{\text {cde }}$ & $2.63 \pm 0.08^{b c d e}$ & $12.77 \pm 0.71^{a b c}$ & $22.67 \pm 0.22^{a b}$ \\
\hline \multicolumn{6}{|c|}{ Two-way ANOVA } \\
\hline C & & $* *$ & NS & $* * *$ & $* * *$ \\
\hline IC & & $* * *$ & $*$ & $*$ & $* *$ \\
\hline \multicolumn{2}{|l|}{$\mathrm{C} \times \mathrm{IC}$} & $* * *$ & $* * *$ & $* * *$ & $* * *$ \\
\hline \multirow{3}{*}{ Compost rates } & \multirow{3}{*}{ Inoculation } & \multicolumn{4}{|c|}{ jew's mallow } \\
\hline & & \multicolumn{2}{|c|}{ Dry weight $\left(\mathrm{g} \mathrm{plant}^{-1}\right)$} & \multicolumn{2}{|c|}{ Plant height $\left(\mathrm{cm}\right.$ plant $\left.^{-1}\right)$} \\
\hline & & Root & Shoot & \multicolumn{2}{|c|}{ Shoot } \\
\hline \multirow{4}{*}{0 t ha ${ }^{-1}$} & $\mathrm{NC}$ & $0.18 \pm 0.02^{a}$ & $1.73 \pm 0.16^{a}$ & \multicolumn{2}{|c|}{$28.27 \pm 1.07^{a}$} \\
\hline & $\mathbf{M}$ & $0.27 \pm 0.02^{c}$ & $2.61 \pm 0.004^{b}$ & \multicolumn{2}{|c|}{$33.12 \pm 0.65^{b}$} \\
\hline & $\mathbf{A M}$ & $0.37 \pm 0.02^{f g}$ & $4.07 \pm 0.17^{g}$ & \multicolumn{2}{|c|}{$42.28 \pm 3.42^{e}$} \\
\hline & NC & $0.33 \pm 0.01^{d e}$ & $3.22 \pm 0.24^{\text {def }}$ & \multicolumn{2}{|c|}{$38.25 \pm 0.18^{c d}$} \\
\hline \multirow{3}{*}{$5 \mathrm{tha}^{-1}$} & $\mathbf{M}$ & $0.40 \pm 0.02^{g}$ & $3.95 \pm 0.09^{g}$ & \multicolumn{2}{|c|}{$40.63 \pm 2.03^{d e}$} \\
\hline & $\mathbf{A M}$ & $0.35 \pm 0.01^{e f}$ & $3.86 \pm 0.25^{g}$ & \multicolumn{2}{|c|}{$42.47 \pm 0.3^{e}$} \\
\hline & $\mathrm{NC}$ & $0.29 \pm 0.01^{c}$ & $2.92 \pm 0.07^{b c}$ & \multicolumn{2}{|c|}{$32.18 \pm 0.50^{b}$} \\
\hline \multirow[t]{3}{*}{$10 \mathrm{tha}^{-1}$} & $\mathbf{M}$ & $0.29 \pm 0.01^{c}$ & $2.70 \pm 0.05^{b c}$ & 32.7 & $80^{b}$ \\
\hline & $\mathbf{A M}$ & $0.36 \pm 0.02^{e f}$ & $3.95 \pm 0.07^{g}$ & 39.92 & $25^{\text {cde }}$ \\
\hline & NC & $0.24 \pm 0.02^{b}$ & $2.95 \pm 0.16^{b c d}$ & 32.3 & $57^{b}$ \\
\hline $15 \mathrm{t} \mathrm{ha}^{-1}$ & $\mathbf{M}$ & $0.30 \pm 0.003^{c d}$ & $3.04 \pm 0.09^{c d e}$ & 37.4 & $32^{c}$ \\
\hline & AM & $0.37 \pm 0.002^{f g}$ & $4.01 \pm 0.04^{g}$ & 39.24 & $87^{c d}$ \\
\hline Two-way ANO & & & & & \\
\hline C & & $* * *$ & $* * *$ & & \\
\hline IC & & $* * *$ & $* * *$ & & \\
\hline C x IC & & $* * *$ & $* * *$ & & \\
\hline
\end{tabular}

NC: plants without inoculation; M: plants inoculated with microbes; AM: plants inoculated with arbuscular mycorrhizal fungi; C: effect of compost; IC: effect of inoculation; C x IC: the effect of interaction between compost and inoculation; One-way ANOVA was performed for amendment treatments; Means for each parameter with different letters are significantly different from each other $(\mathrm{P}<$ 0.05) according to the Duncan test; Two-way ANOVA was performed to determine the effect of compost, inoculation and interaction between compost and inoculation to polluted soil. NS not significant; *P $<0.05 ; * * \mathrm{P}<0.01 ; * * * \mathrm{P}<0.001$

\section{Mycorrhizal colonization}

It was observed that jew's mallow roots colonization was higher than that carrot roots. There were large differences between colonization patterns in carrot roots (Fig. 1A). The colonized roots occupied by intercellular, intracellular hyphae, arbuscules and vesicles. Microscopic analysis confirmed that plants of non- inoculation treatment were not colonized by AM. As is evident from Fig. 1A, in roots of carrot plants treated with compost $\left(10 \mathrm{t} \mathrm{ha}^{-1}\right)$, the highest value of hyphae, vesicles and arbuscular colonization was recorded. Also, the highest proportion of mycorrhizal colonization structure in jew's mallow plants such as hyphae, vesicles and arbuscular at compost (10 t ha $\left.{ }^{-1}\right)$ (Fig. 1B). 

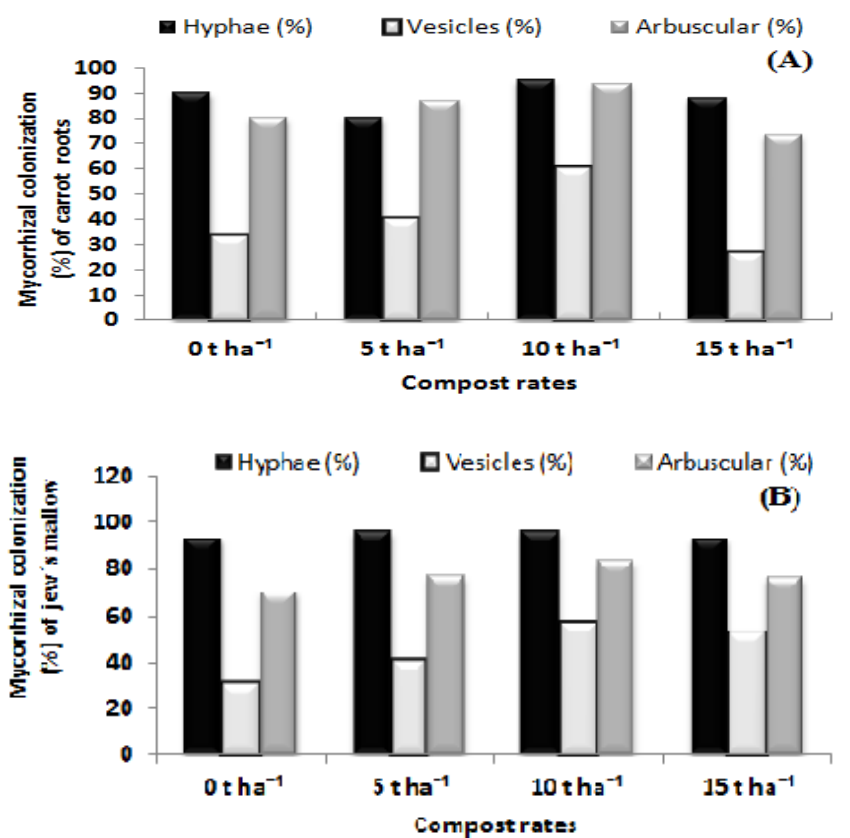

Figure 1: Percentage of mycorrhizal fungi colonized roots of (A) carrot and (B) jew's mallow

\section{Cadmium concentration}

Data in Figure 2(A-D) observed that the concentration of $\mathrm{Cd}$ in both plants was decreased significantly $(\mathrm{P}<0.05)$ with compost incorporation and microorganisms inoculations. The highest value of $\mathrm{Cd}$ concentration was observed in control treatment (mineral fertilizers only) of both plants. Meanwhile, Cd concentration in roots and shoots of carrot plants was lower than in roots and shoots of jew's mallow. The concentration of $\mathrm{Cd}$ in shoots of the tested plants was slightly higher than in roots. The data showed that the compost incorporation with microbes or AM fungi decreased uptake of Cd. The lowest level of $\mathrm{Cd}$ (66.6\% reduction) was observed in roots of carrot grown in polluted soil incorporated with compost at $15 \mathrm{t} \mathrm{ha}^{-1}$ and inoculated with AM while in shoots the lowest level recorded $65.52 \%$ reduction in soil treated with compost (15 $\mathrm{t} \mathrm{ha}^{-1}$ ) inoculated with microbes. Concerning to jew's mallow, the residual effect of $5 \mathrm{t}$ compost $\mathrm{ha}^{-1}$ and $\mathrm{AM}$ fungi attained the highest reduction in roots $(87.92 \%)$ while in shoots, the lowest level observed in $15 \mathrm{t}$ compost ha $^{-1}+$ AM by $86.48 \%$. Cadmium levels of carrot (root vegetables) and jew's mallow (leaf vegetables) were higher than the maximum level $\left(0.1\right.$ and $0.2 \mathrm{mg} \mathrm{kg}^{-1}$, respectively) recommended by WHO/FAO (2010).

\section{Nickel concentration}

The effect and residual effect of compost incorporation on Ni uptake by roots and shoots of carrot and subsequent jew's mallow is shown in Figure 3 (A-D). The lowest Ni concentration $(64.60 \%$ reduction) recorded in roots of carrot grown in polluted soil and incorporated with compost $\left(15 \mathrm{t} \mathrm{ha}^{-1}\right)$ and AM fungi. On the other hand, the highest reduction $(65.71 \%)$ in $\mathrm{Ni}$ concentration in shoots of carrot was detected in compost $\left(15 \mathrm{t} \mathrm{ha}^{-1}\right)$ and microbes inoculation. The data showed that the $\mathrm{Ni}$ concentration in carrot plants decreased with increasing compost rates and inoculation with microorganisms.
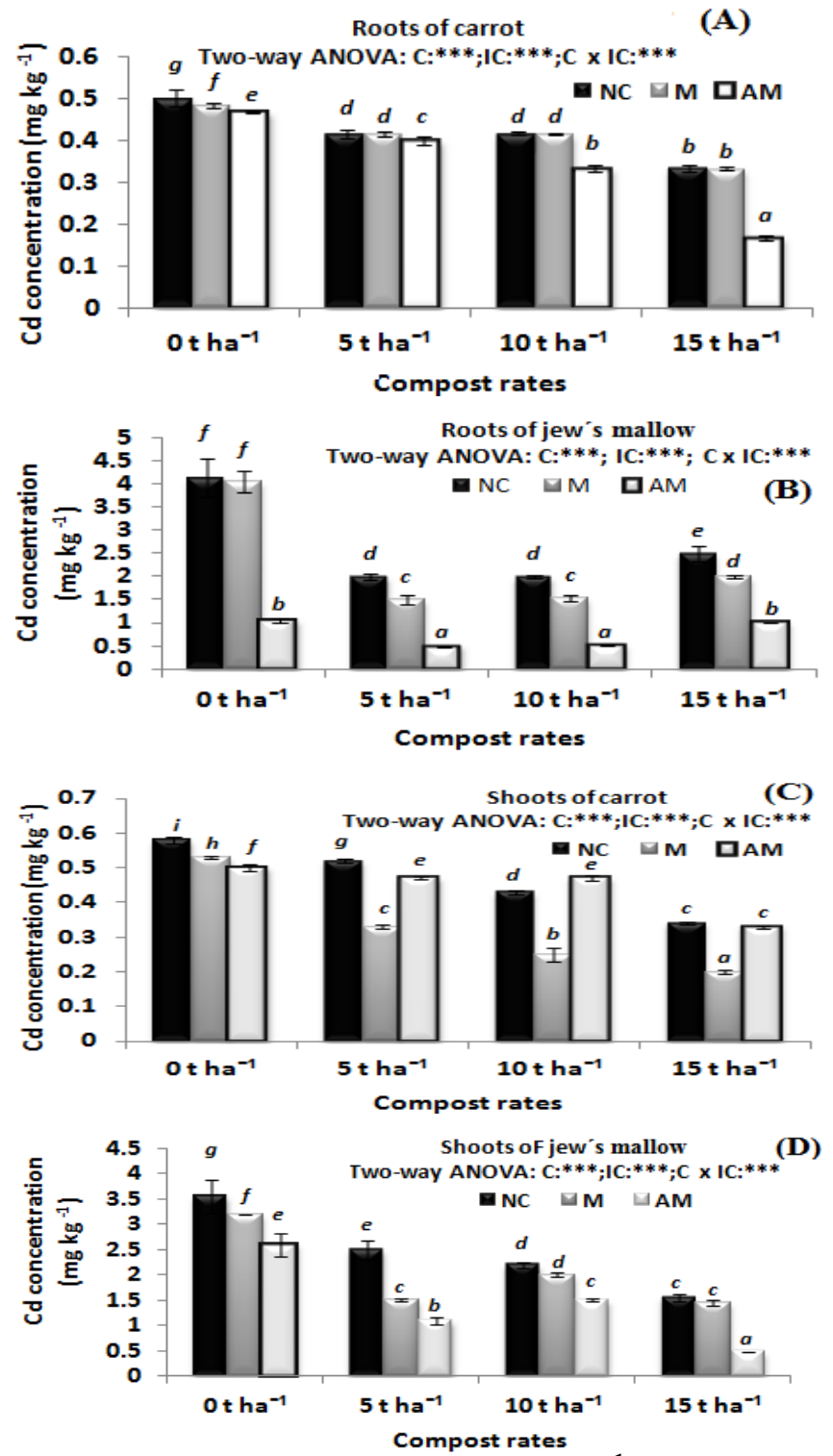

Figure 2 (A-D): Cd concentration $\left(\mathrm{mg} \mathrm{kg}^{-1} \mathrm{DW}\right)$ in roots and shoots of carrot and jew's mallow, Mean \pm SD $(n=3)$

One-way ANOVA was performed for amendment treatments; Means for each parameter with different letters are significantly different from each other $(\mathrm{P}<0.05)$ according to the Duncan test; 
Two-way ANOVA was performed to determine the effect of compost, inoculation and interaction between compost and inoculation to polluted soil. NS not significant; $* \mathrm{P}<0.05 ; * * \mathrm{P}<$ $0.01 ; * * * \mathrm{P}<0.001$
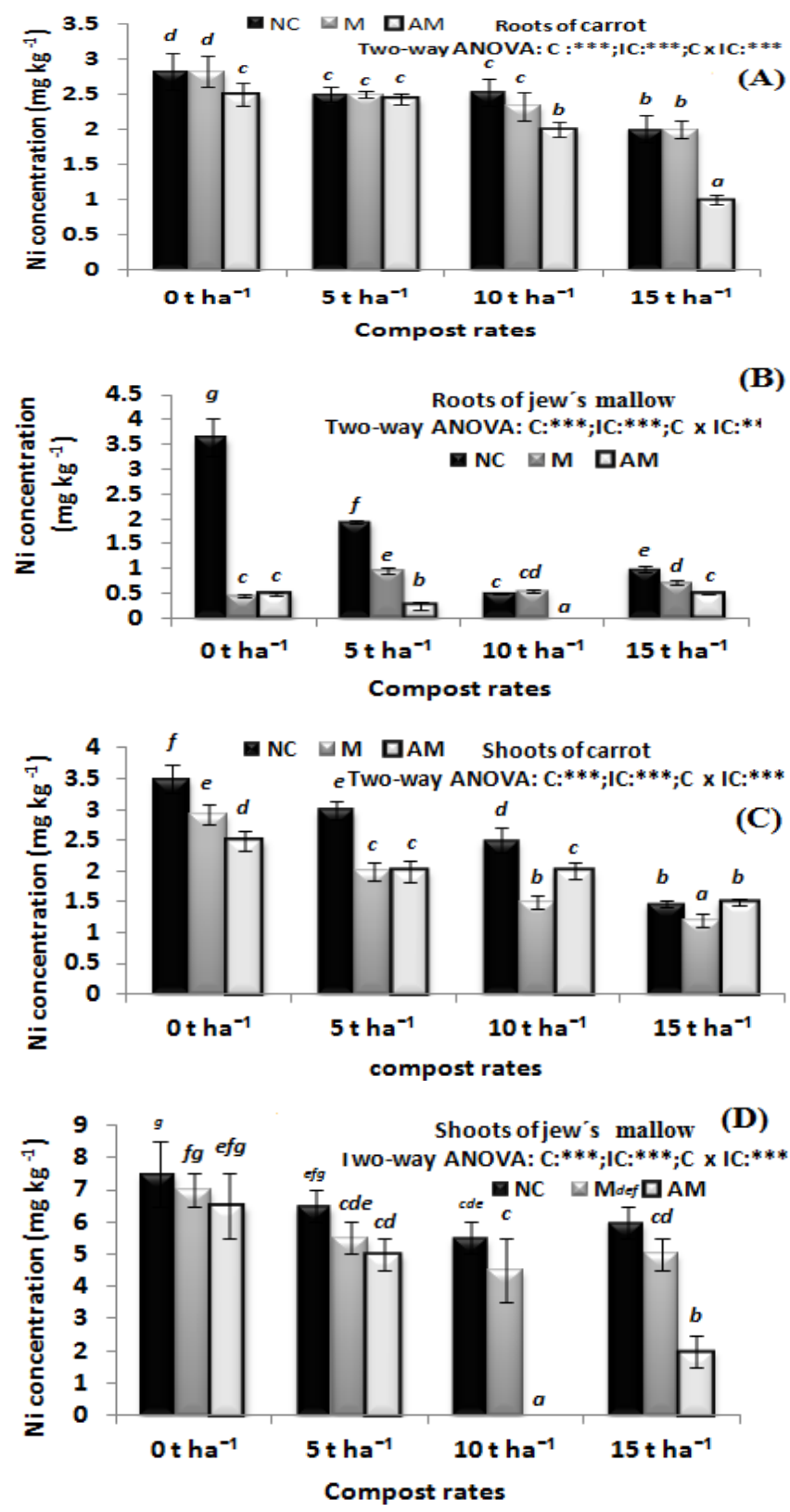

Figure 3 (A-D): Ni concentration $\left(\mathrm{mg} \mathrm{kg}^{-1} \mathrm{DW}\right)$ in roots and shoots of carrot and jew's mallow, Mean $\pm \mathrm{SD}(\mathrm{n}=3)$.

One-way ANOVA was performed for amendment treatments; Means for each parameter with different letters are significantly different from each other $(\mathrm{P}<0.05)$ according to the Duncan test; Two-way ANOVA was performed to determine the effect of compost, inoculation and interaction between compost and inoculation to polluted soil. NS not significant; *P $<0.05$; **P $<$ $0.01 ; * * * \mathrm{P}<0.001$

Meanwhile, Ni concentration in roots and shoots of jew's mallow fluctuated as a result of residual effects of compost and microorganisms. The lowest concentration of $\mathrm{Ni}$ recorded in shoots and roots of jew's mallow treated with compost $\left(10 \mathrm{t} \mathrm{ha}^{-1}\right)$ and AM fungi while the highest concentration recorded in control plants (mineral fertilizers only). Nickel levels of carrot and jew's mallow plants were higher than critical level $\left(0.01 \mathrm{mg} \mathrm{kg}^{-1}\right)$ recommended by WHO/FAO (2007). Two-way ANOVA indicated an extremely significant $(\mathrm{P}<0.001)$ for the factor "compost", "inoculation" and for the interaction of " compost $\mathrm{x}$ inoculation" between treatments for $\mathrm{Cd}$ and $\mathrm{Ni}$ concentrations of both plants.

\section{Bioavailability of $\mathrm{Cd}$ and $\mathrm{Ni}$ in soil}

Data in Table (4) revealed that available content of $\mathrm{Cd}$ and $\mathrm{Ni}$ were found in soils after harvesting of carrot and jew's mallow. Results pointed that the DTPA extractable Cd and $\mathrm{Ni}$ in soil after harvesting jew's mallow was higher than in carrot soil. The soil $\mathrm{Cd}$ and $\mathrm{Ni}$ availability under compost, inoculations and their residual effects were the lowest. In the case of carrot soil, the lowest DTPA extractable $\mathrm{Cd}$ and $\mathrm{Ni}$ was observed with compost (15 t ha ${ }^{1}$ ) and AM inoculation (0.106 and $0.596 \mathrm{mg} \mathrm{kg}^{-1}$ dry soil, respectively) with a reduction $17.19 \%$ and $18.58 \%$, respectively. In relation to jew's mallow soil, the lowest DTPA extractable $\mathrm{Cd}$ and $\mathrm{Ni}$ was detected with residual effect of AM inoculation without compost (0.108 and 0.472 $\mathrm{mg} \mathrm{kg}^{-1}$ dry soil, respectively) with a reduction $41.94 \%$ and $62.48 \%$, respectively. The highest DTPA extractable of Cd and $\mathrm{Ni}$ was showed in untreated soils (mineral fertilizers only).

\section{Transfer factor (TF) from soil to plants}

The transfer factor (TF) for $\mathrm{Cd}$ and $\mathrm{Ni}$ build up in the plant tissues (Figure 4) indicated that TF for $\mathrm{Cd}$ and $\mathrm{Ni}$ were found to be lower than 1 except non-inoculated jew's mallow plants and inoculated with microbes grown at zero compost. It was observed that the $\mathrm{TF}$ of $\mathrm{Cd}$ was higher than $\mathrm{TF}$ of $\mathrm{Ni}$ in tested plants. The highest $\mathrm{TF}$ of $\mathrm{Cd}$ and $\mathrm{Ni}$ was observed at zero compost (mineral fertilizers only) recorded 0.25 and 0.11 in carrot and 1.75 and 0.19 in jew's mallow, respectively. $\mathrm{TF}$ of $\mathrm{Cd}$ and $\mathrm{Ni}$ is quite high in the leafy plants ( $C$. olitorius L.) compared to root vegetable ( $D$. carota L.). Data revealed that TF decreased increasing of compost rates, where the lowest TFs of $\mathrm{Cd}$ was detected in the two test plants grown in soil treated with $15 \mathrm{t}$ compost $\mathrm{ha}^{-1}$ and inoculated with AM. Meanwhile, the lowest TF of $\mathrm{Ni}$ were observed in carrot grown at $15 \mathrm{t} \mathrm{ha}^{-1}$ of compost and inoculated with AM registered 0.045 but in jew's 
Table 4: Available Cd and Ni of carrot and jew's mallow soils after harvesting, Mean \pm SD ( $n=3$ )

\begin{tabular}{|c|c|c|c|c|c|}
\hline \multirow{2}{*}{ Compost rates } & \multirow{2}{*}{ Inoculation } & \multicolumn{2}{|c|}{ carrot } & \multicolumn{2}{|c|}{ jew's mallow } \\
\hline & & $\begin{array}{c}\text { Available Cd } \\
\left(\mathrm{mg} \mathrm{kg}^{-1}\right)\end{array}$ & $\begin{array}{c}\text { Available Ni } \\
\left(\mathrm{mg} \mathrm{kg}^{-1}\right)\end{array}$ & $\begin{array}{c}\text { Available Cd } \\
\left(\mathrm{mg} \mathrm{kg}^{-1}\right)\end{array}$ & $\begin{array}{c}\text { Available Ni } \\
\left(\mathrm{mg} \mathrm{kg}^{-1}\right)\end{array}$ \\
\hline \multirow{3}{*}{0 t ha ${ }^{-1}$} & $\mathbf{N C}$ & $0.128 \pm 0.004^{h}$ & $0.732 \pm 0.002^{i}$ & $0.186 \pm 0.01^{h}$ & $1.258 \pm 0.10^{h}$ \\
\hline & $\mathbf{M}$ & $0.126 \pm 0.002^{g h}$ & $0.694 \pm 0.004^{h}$ & $0.156 \pm 0.004^{g}$ & $1.256 \pm 0.01^{h}$ \\
\hline & $\mathbf{A M}$ & $0.118 \pm 0.002^{\text {cde }}$ & $0.664 \pm 0.002^{e f}$ & $0.108 \pm 0.01^{a}$ & $0.472 \pm 0.01^{a}$ \\
\hline \multirow[t]{3}{*}{5 t ha $^{-1}$} & NC & $0.118 \pm 0.002^{\text {cde }}$ & $0.652 \pm 0.003^{d}$ & $0.110 \pm 0.02^{\mathrm{ab}}$ & $0.564 \pm 0.02^{c}$ \\
\hline & $\mathbf{M}$ & $0.124 \pm 0.001^{f g h}$ & $0.688 \pm 0.002^{h}$ & $0.130 \pm 0.01^{c d e f}$ & $0.614 \pm 0.01^{d}$ \\
\hline & $\mathbf{A M}$ & $0.116 \pm 0.002^{c d}$ & $0.652 \pm 0.004^{d}$ & $0.118 \pm 0.01^{a b c d}$ & $0.530 \pm 0.01^{b c}$ \\
\hline \multirow[t]{3}{*}{10 t ha $^{-1}$} & NC & $0.110 \pm 0.002^{a b}$ & $0.608 \pm 0.002^{b}$ & $0.134 \pm 0.01^{\text {def }}$ & $0.705 \pm 0.01^{e}$ \\
\hline & $\mathbf{M}$ & $0.120 \pm 0.003^{d e f}$ & $0.666 \pm 0.006^{f}$ & $0.140 \pm 0.01^{e f g}$ & $0.722 \pm 0.01^{e f}$ \\
\hline & $\mathbf{A M}$ & $0.114 \pm 0.002^{b c}$ & $0.640 \pm 0.002^{c}$ & $0.122 \pm 0.02^{a b c d e}$ & $0.508 \pm 0.01^{a b}$ \\
\hline \multirow[t]{3}{*}{$15 \mathrm{t} \mathrm{ha}^{-1}$} & NC & $0.108 \pm 0.001^{a}$ & $0.598 \pm 0.004^{a}$ & $0.140 \pm 0.02^{e f g}$ & $0.758 \pm 0.01^{f}$ \\
\hline & $\mathbf{M}$ & $0.114 \pm 0.003^{b c}$ & $0.634 \pm 0.004^{c}$ & $0.158 \pm 0.014^{g}$ & $0.874 \pm 0.01^{g}$ \\
\hline & $\mathbf{A M}$ & $0.106 \pm 0.002^{a}$ & $0.596 \pm 0.006^{a}$ & $0.120 \pm 0.01^{a b c d}$ & $0.540 \pm 0.01^{b c}$ \\
\hline \multicolumn{6}{|l|}{ Two-way ANOVA } \\
\hline $\mathbf{C}$ & & $* * *$ & $* * *$ & $* * *$ & $* * *$ \\
\hline IC & & $* * *$ & $* * *$ & $* * *$ & $* * *$ \\
\hline $\mathrm{C} \times \mathrm{IC}$ & & $* * *$ & $* * *$ & $* * *$ & $* * *$ \\
\hline
\end{tabular}

NC: plants without inoculation; M: plants inoculated with microbes; AM: plants inoculated with arbuscular mycorrhizal fungi; C: effect of compost; IC: effect of inoculation; C x IC: the effect of interaction between compost and inoculation; One-way ANOVA was performed for amendment treatments; Means for each parameter with different letters are significantly different from each other $(\mathrm{P}<$ 0.05) according to the Duncan test; Two-way ANOVA was performed to determine the effect of compost, inoculation and interaction between compost and inoculation to polluted soil. NS not significant; $* \mathrm{P}<0.05$; **P $<0.01 ; * * * \mathrm{P}<0.001$

mallow the lowest $\mathrm{TF}$ of $\mathrm{Ni}$ observed at $10 \mathrm{t}$ compost $\mathrm{ha}^{-1}$ and AM inoculation as depicted in Figure 4.

\section{Discussion}

Compost application can improve the physical structure, fertility of soil and microbial activity (Tian et al., 2015) that have a positive impact on carrot biomass. Also, residual effect of compost induced higher biomass of jew's mallow plants which might be due to slow release of nutrients from compost which are available to plants. Several studies reported that compost application, besides improving the physico-chemical properties of the soil, slowly releases nutrients and prevents nutrient losses from the inorganic fertilizers by binding to nutrients and releasing them with time (Arshad et al., 2004; Abedi et al., 2010; Demelash et al., 2014). On the other hand, mineral fertilizers play a role in increasing plant biomass but these fertilizers may also contain some toxic elements such as cadmium, lead and/or arsenic (Grant and Sheppard, 2008).

The microbes (fungal-bacterial inoculum) and arbuscular mycorrhizal fungi (AMF) inoculation attained a positive increase in plant growth when applied alone or combined with compost. Microbial inoculants consists of living cells of microorganism like bacteria, algae and fungi alone or combination which may help in increasing crop productivity. Biological activities are markedly enhanced by microbial interactions in the rhizosphere of plants (Tilak and Reddy, 2006). An investigation with marjoram (Majorana hortensis L.) indicated that the use of combined treatment of bio-fertilizers gave better results for all studied traits (Gharib et al., 2008). In the same respect, the positive effects of bacteria on the growth of apricot, raspberry, tomatoes, sugar beet, apple, sweet cherry, and barley have been explained by the ability of these bacteria to produce auxin and cytokinin and solubilize phosphate (Esitken et al., 2010). Many studies showed that Mycorrhizal inoculation increase plant biomass than non-mycorrhizal one (Leung et al., 2007, 2010). The increased biomass production of mycorrhizal plants may be due to better root development, which in turn promoted dry matter weight. This indicates that plants' ability to channel energy for shoot production was increased due to the symbiotic association of AM fungi with plant root system (Benthlenfalbay et al., 1982). The current and residual effects of compost and microorganisms have reduced $\mathrm{Cd}$ and Ni contents in carrot and jew's mallow parts. Compost utilization can change heavy metals mobility and bioavailability in agriculture soil and therefore the toxicity on plants. These actions are attributed to various processes, including adsorption, complexation, precipitation, and redox reactions (Huang et al., 2016). 

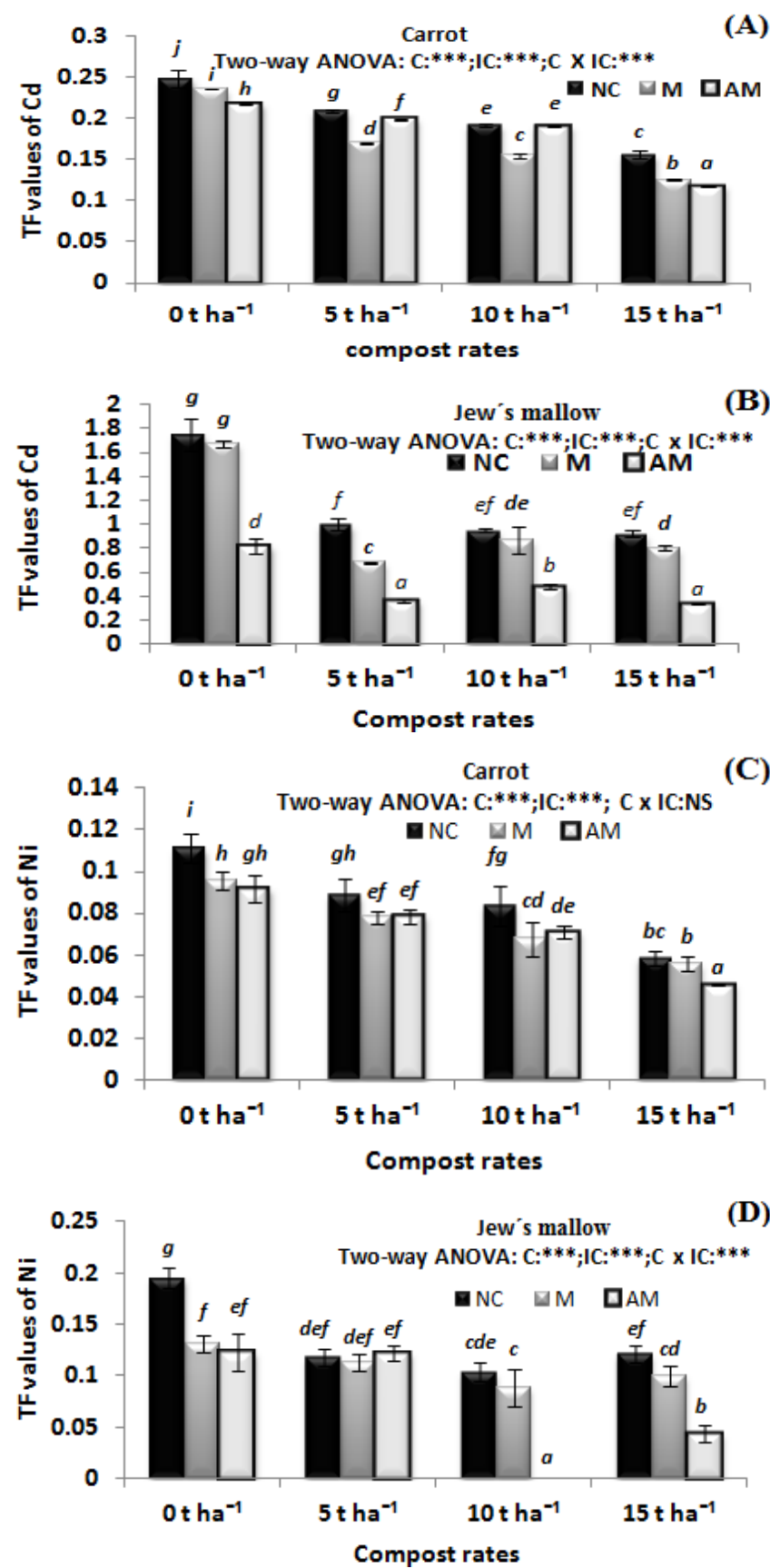

Figure 4 (A-D): Transfer factor (TF) values of $\mathrm{Cd}$ and $\mathrm{Ni}$ in total plants of carrot and jew's mallow, Mean \pm SD $(n=3)$

One-way ANOVA was performed for amendment treatment; Means for each parameter with different letters are significantly different from each other $(\mathrm{P}<0.05)$ according to the Duncan test; Two-way ANOVA was performed to determine the effect of compost, inoculation and interaction between compost and inoculation to polluted soil. NS not significant; $* \mathrm{P}<0.05$; $* * \mathrm{P}<$ $0.01 ; * * \mathrm{P}<0.001$
Generally, reducing the risk of crop failure and economic losses, and decreasing human health risks from heavy metals may be achieved by using compost. Microbes play a vital role in the reduction of heavy metals especially those isolated from the polluted soil because they have a tolerant to a higher concentration of metals than those isolated from unpolluted soil (Rajkumar et al., 2010). Soil microbes have developed many mechanisms such as bioaccumulation the metal ions inside the cell, biotransformation of toxic metals to less toxic forms and metal adsorption on the cell to reduce the toxicity of heavy metals. From our results, the fungal - bacterial inoculation had a double effect where it increased shoot and root biomass and reduced the concentration of $\mathrm{Cd}$ and $\mathrm{Ni}$ in plants tissues in agreement with Seneviratne et al. (2015). Also, Arbuscular mycorrhizal (AM) fungi play a significant role in increasing plants tolerance to toxic metal contamination by producing glycoprotein called glomalin which has heavy metal binding sites (Trotta et al., 2006). Not only the combination between compost and microorganisms inoculation has an effective role in the reduction of $\mathrm{Cd}$ and $\mathrm{Ni}$ levels but also the residual effects of these amendments have the same feature. This might be attributed to that compost contains humic substances and mineral ions which stimulate the metabolic activity of microorganisms that might have effect on the immobilization of heavy metals and reduced the toxicity generated by these metals in agriculture soils.

The positive reduction of $\mathrm{Cd}$ and $\mathrm{Ni}$ availability in soils of both plants as a result of the direct and indirect effect of compost and microorganisms has been shown. A number of studies pointed that compost amendment can reduce heavy metals bioavailability in soil depending on organic matter humification and soil pH (Walker et al., 2003, 2004). Results showed that the application of Arbuscular mycorrhizal fungi individually or combined with compost and its residual effect attained the minimum values of DTPA-extractable of $\mathrm{Cd}$ and $\mathrm{Ni}$ which reflect the critical role of AMF in decreasing the bioavailability of these metals in soil and consequently reduce metal accumulation in plant tissues.

The transfer factor describes the amount of an element expected to enter a plant from its substrate, under equilibrium conditions (Sheppard and Sheppard, 1985; Davis et al., 1999). The leafy vegetable (C. olitorius L.) are found to show a higher transfer factor for $\mathrm{Cd}$ and $\mathrm{Ni}$ than in root vegetable (D. carota $\mathrm{L}$.). The present result agrees with the investigation made by Zhuang et al. (2009) and Jolly et al. (2013) where the transfer factors for heavy metals were significantly higher for leafy than non-leafy vegetables. Leaf vegetables generally grow faster with higher transpiration rates than non-leaf vegetables (Luo et al., 
2011). Thus, metal uptake by plant roots can be enhanced in leaf vegetables, resulting in the translocation of metals from roots to other vegetable tissues (Stalikas et al., 1997; Zheng et al., 2007).

\section{Conclusion}

The direct and residual effect of compost and microorganisms individually or in combination on the bioavailability of $\mathrm{Cd}$ and $\mathrm{Ni}$ to carrot and jew's mallow were examined. Amendments improved yields biomass of root and shoots of carrot and jew's mallow plants. Mycorrhizal colonization of jew's mallow (residual effect) was higher than carrot (direct effect). Cadmium and nickel concentration in plants tissues decreased gradually by increasing compost rate. The combination of compost and microorganisms further decreased metals concentrations in plants than sole application of compost. The current study suggests that the combination of compost and microorganisms especially, with AMF could be important bio-resource for remediation of the metal polluted soil.

\section{References}

Abedi, T., A. Alemzadeh, and S.A. KazemeIni. 2010. Effect of organic and inorganic fertilizers on grain yield and protein banding pattern of wheat. Australian Journal of Crop Science 4:384-389.

Alemayehu, E., and B. Lennartz. 2010. Adsorptive removal of nickel from water using volcanic rocks. Applied Geochemistry 25:1596-1602.

Al-Hamdan, A.Z., and K.R. Reddy. 2006. Adsorption of heavy metals in glacial till soil. Geotechnical and Geological Engineering 24:1679-1693.

Angelova, V.A., B. Radka Ivanova, C. Galina Pevicharova and I. Krasimir. 2010. Effect of organic amendments on heavy metals uptake by potato plants. In: 19th World congress of soil science, soil solutions for a changing world, 1-6 August 2010, Brisbane, Australia.

AOAC. 1990. AOAC official methods of analysis. 15th ed. Association of Official Analytical Chemists, Arlington, Virginia, pp. 84-85.

Arshad, M., A. Khalid, M.H. Mahmood, and Z.A. Zahir. 2004. Potential of nitrogen and L-tryptophan enriched compost for improving growth and yield of hybrid maize. Pakistan Journal of Agriculture Science 41:1624.

Aziz, H., M. Sabir, H.R. Ahmad, T. Aziz, M. Zia-urRehman, K.R. Hakeem, and M. Ozturk. 2015. Alleviating effect of calcium on nickel toxicity in rice. Clean Soil Air Water 43: 901-909.

Barea, J.M., M.J. Pozo, R. Azcón, and C. Azcón-Aguilar. 2005. Microbial co-operation in the rhizosphere. Journal of Experimental Botany 56: 1761-1778.
Benthlenfalbay, G.J., R.S. Pacovsky, H.G. Bayne, and A.E. Stafford. 1982. Interactions between nitrogen fixation, mycorrhizal colonization and host plant growth in the Phaseolus-Rhizobium-Glomus symbiosis. Plant Physiology 70: 446-450.

Black, C.A., D.D. Evans, L.E. Ensminger, J.L. white, F.E. Clark, and R.C. Dinauer. 1965. "Methods of Soil Analysis". П Chemical and Microbiological Properties. American Society of Agronomy, Madison, Wisconsin., USA.

Correa, A.X.D.R., L.R. Rorig, M.A. Verdinelli, S. Cotelle, J.F. Ferard, and C.M. Radetski. 2006. Cadmium phytotoxicity: Quantitative sensitivity relationships between classical endpoints and antioxidative enzyme biomarkers. Science of the Total Environment 357(13): 120-127.

Cottenie, A., M. Varloo, I. Kiekens, G. Velghe, and R. Camerlynck. 1982. Chemical Analysis of Plants and Soils. Laboratory of analytical and agrochemistry State University, Ghent, Belgium.

Cui, Y.J., Y.G. Zhu, R.H. Zhai, D.Y. Chen, Y.Z. Huang, Y. Qui, and J.Z. Liang. 2004. Transfer of metals from soil to vegetables in an area near a smelter in Nanning, China. Environment International 30: 785-791.

Davis, P.A., M.R. Avadhanula, D. Cancio, P. Carboneras, P. Coughtrey, G. Johansson, and et al. 1999. BIOMOVS II: an international test of the performance of environmental transfer models. Journal of Environmental Radioactivity 42:117-30.

Demelash, N., W. Bayu, S. Tesfaye, F. Ziadat, and R. Sommer 2014. Current and residual effects of compost and inorganic fertilizer on wheat and soil chemical properties. Nutrient Cycling in Agroecosystems 100: 357-367.

Dixit, R., D. Malaviya, K. Pandiyan, U.B. Singh, A. Sahu, R. Shukla, and D. Paul. 2015. Bioremediation of Heavy metals from soil and aquatic environment: An Overview of principles and criteria of fundamental processes. Sustainability 7(2): 2189-2212.

Esitken, A., H.E. Yildiz, S. Ercisli, M. Figen Donmez, M. Turan, and A. Gunes. 2010. Effects of plant growth promoting bacteria (PGPB) on yield, growth and nutrient contents of organically grown strawberry. Scientia Horticulturae 124: 62-66.

Fusconi, A., O. Repetto, E. Bona, N. Massa, C. Gallo, E. Dumas-Gaudot, and G. Berta. 2006. Effects of cadmium on meristem activity and nucleus ploidy in roots of Pisum sativum L. cv. Frisson seedlings. Environmental and Experimental Botany 58: 253-260.

Gerdemann, J.W., and T.H. Nicolson. 1963. Spores of mycorrhizal Endogone extracted from soil by wet sieving and decanting. Transactions of the British Mycological Society 46(2): 235-244. 
Gharib, F.A., L.A. Moussa, and O.N. Massoud. 2008. Effect of compost and bio-fertilizers on growth, yield and essential oil of sweet marjoram (Majorana hortensis) plant. International journal of agriculture \& biology 10: 381-387.

Grant, C.A., and S.C. Sheppard. 2008. Fertilizer impacts on cadmium availability in agricultural soils and crops. Human and Ecological Risk Assessment 14: 210-228.

Huang, M., Y. Zhu, Z. Li, B. Huang, N. Luo, C. Liu, and G. Zeng. 2016. Compost as a soil amendment to remediate heavy metal contaminated agricultural soil: mechanisms, efficacy, problems, and strategies. Water Air Soil Pollution pp. 227:359.

INVAM. 2006. Internacional Culture Collection of (Vesicular) Arbuscular Mycorrhizal Fungy. Http://invam.caf.wvu.edu. (2 de enero del 2006).

Jackson, M.L. 1973. "Soil Chemical Analysis". PrenticeHall of India Private Limited, New Delhi.

Jolly, Y.N., A. Islam, and S. Akbar. 2013. Transfer of metals from soil to vegetables and possible health risk assessment. Springer Plus 2(1): 385.

Klute, A. 1986. Methods of soil analysis. Part-1. Physical and mineralogical methods. $2^{\text {nd }}$ Edition American Society of Agronomy, Madison, Wisconsin, USA.

Kuo, C., and H. Kao. 2004. Antioxidant enzyme activities are up regulated in response to cadmium in sensitive, but not in tolerant, rice (Oryza sativa) seedlings. Botanical Bulletin of Academia Sinica 45: 291-299.

Lai, Y., B. Xu, L. He, M. Lin, L. Cao, Y. Wu, S. Mou, and S. He. 2012. Cadmium uptake by and translocation within rice (Oryza sativa L.) seedlings as affected by iron plaque andFe $\mathrm{O}_{3}$. Pakistan Journal of Botany 44(5): 1557-1561.

Leung, H.M., Z.H. Ye, and M.H. Wong. 2007. Survival strategies of plants associated with arbuscular mycorrhizal fungi on toxic minetailings. Chemosphere 66: 905-915.

Leung, H.M., F.Y. Wua, K.C. Cheunga, Z.H. Yeb, and M.H. Wonga. 2010. Synergistic effects of arbuscular mycorrhizal fungi and phosphate rock on heavy metal uptake and accumulation by an arsenic hyperaccumulator. Journal of Hazardous Materials 181: 497-507.

Lindsay, W.L., and W.A. Norvell. 1978. Development of a DTPA soil test for zinc, iron, manganese, and copper. Soil Science Society of America Journal 42: 421-428.

Leslie, J.F., and B.A. Summerell. 2006. The Fusarium Laboratory manual. (Blackwell Publishing: Iowa, USA).

Liu, J., Q. Zhu, Z. Zhang, J. Xu, J. Yang, and M.H. Wong. 2004. Variations in cadmium accumulation among rice cultivars and types and the selection of cultivars for reducing cadmium in the diet. Journal of the Science of Food and Agriculture 85: 147-153.

Luo, C.L., C.P. Liu, Y. Wang, X. Liu, F.B. Li, C. Zhang, and X.D. Li. 2011. Heavy metal contamination in soils and vegetables near an e-waste processing site, south China. Journal of Hazardous Materials 186: 481-490.

Mclean, E.O. 1982. Soil ph and Lime requirement. In: Methods of soil analysis Part2. Agronomy. A.L. Page (ed) American Society of Agronomy Madison, 101. USA:199 - 234 .

Mohammad, N., M.Z. Alam, and N.A. Kabbashi. 2011. Development of compatible fungal mixed culture for composting process. African Journal of Biotechnology 10(81): 18657-18665.

Morgan, J.A.W., G.D. Bending, and P.J. White. 2005. Biological cost and benefits to plant microbe interactions in then rhizosphere. Journal of Experimental Botany 56: 1729-1739.

Navarro, A.F., J. Cegarra, A. Roig, and D. Garcia. 1993. Relationships between organic matter and carbon contents of organic waste. Bioresource Technology 44: 203-207.

Page, A.L., R.H. Miller, and D.R. keeney. 1982. "Methods of Soil Analysis". П Chemical and Microbiological Properties. American Society of Agronomy, Madison, Wisconsin., USA.

Phillips, J.M., and D.S. Hayman. 1970. Improved procedures for clearing roots and staining parasitic and vesicular-arbuscular mycorrhizal fungi for rapid assessment of infection. Transactions of the British Mycological Society 55: 158-161.

Piper, C.S. 1950. "Soil and Plant Analysis". 1 ${ }^{\text {st }}$ Ed. Inter science Publishers. Inc. New York, pp. 30-229.

Pitt, J.I. 1985. A laboratory guide to common Penicillium species. Academic Press, Australia, pp. 182

Rajkumar, M., N. Ae, M.N.V. Prasad, and H. Freitas. 2010. Potential of siderophore producing bacteria for improving heavy metal phytoextraction. Trends in Biotechnology 28:142-149.

Raper, K.B. and D.I. Fennell. 1965. The Genus Aspergillus. Williams \& Wilkins, Baltimore.

Sandalio, L.M., H.C. Dalurzo, M. Gómez, M.C. RomeroPuertas, and L.A. del Río. 2001. Cadmium-induced changes in the growth and oxidative metabolism of pea plants. Journal of Experimental Botany 52: 2115-2126.

Sangwan, P., V. Kumar, R.S. Khatri, and U.N. Joshi1. 2013. Chromium (VI) Induced Biochemical Changes and GumContent in Cluster Bean (Cyamopsis tetragonoloba L.) at Different Developmental Stages. Journal of Botany Volume 2013, 8 pages.

Seneviratne, M., G. Seneviratne, H.M.S.P. Madawala, M. Iqbal, N. Rajakaruna, T. Bandara, and M. Vithanage. 2015. A preliminary study of the role of bacterial- 
fungal co-inoculation on heavy metal phytotoxicity in serpentine soil. Australian Journal of Botany 63: 261268.

Sheppard, M.I., and S.C. Sheppard. 1985. The plant concentration concept as applied to natural uranium. Health Physics 48: 494 - 500.

Stalikas, C.D., C.I. Chaidou, and G.A. Pilidis. 1997. Enrichment of PAHs and heavy metals in soils in the vicinity of the lignite-fired power plants of West Macedonia (Greece). Science of the Total Environment 204:135-146.

Strong, P.J., and J.E. Burgess. 2008. Treatment methods for wine-related ad distillery wastewaters: a review. Bioremediation Journal 12: 70-87.

Tilak, K.V.B.R., and B.S. Reddy. 2006. B. cereus and B. circulans novel inoculants for crops. Current Science 90:642-644.

Tedesco, M.J., C. Gianello, C.A. Bissani, H. Bohnen, and S.J. Volkweiss. 1995. Analysis of soil, plants and other materials. Technical Bulletin No. 5, 2nd Ed., Federal University of Rio Grande do Sul.

Tian, W., L. Wang, Y. Li, K. Zhuang, G. Li, J. Zhang, and et al. 2015. Responses of microbial activity, abundance, and community in wheat soil after three years of heavy fertilization with manure-based compost and inorganic nitrogen. Agriculture, Ecosystems \& Environment 213: 219-227.

Trotta, A., P. Falaschi, L. Cornara, V. Minganti, A. Fusconi, G. Drava, and G. Berta. 2006. Arbuscular mycorrhize increase the Arsenic translocation factor in the As hyper- accumulating fern Pteris vittate L. Chemosphere 65: 74- 81.
Vidali, M. 2001. Bioremediation: An overview. Pure Applied Chemistry 73:1163-1172.

Walker, D.J., R. Clemente, and M.P. Bernal. 2003. The effects of soil amendments on heavy metal bioavailability in two contaminated Mediterranean soils. Environmental Pollution 122: 303-312.

Walker, C., and A. Schüßler. 2004. Nomenclatural clarifications and new taxa in the Glomeromycota. Mycological Research 108: 979-982.

WHO/FAO. 2007. Food Standard Programme Codex Alimentarius Commission $13^{\text {th }}$ Session. Houston, USA.

WHO/FAO. 2010. Food Standard Programme Codex Alimentarius Commission 5th Session. Japan and Netherlands.

Zheng, N., Q.C. Wang, and D.M. Zheng. 2007. Health risk of $\mathrm{Hg}, \mathrm{Pb}, \mathrm{Cd}, \mathrm{Zn}$, and $\mathrm{Cu}$ to the inhabitants around Huludao zinc plant in China via consumption of vegetables. Science of The Total Environment 383: 8189.

Zhiqiang, X.U., Z. Qixing, and L. Weitao. 2009. Joint effects of cadmium and lead on seedlings of four Chinese cabbage cultivars in northeastern China. Journal of Environmental Sciences 21: 1598-1606.

Zhuang, P., M.B. McBride, H. Xia, N. Li, and Z. Li. 2009. Health risk from heavy metals via consumption of food crops in the vicinity of Dabaoshan mine, South China. Science of the Total Environment 407: 1551-1561. 